\title{
Kematangan Emosi Dan Prososial Pada Relawan Desa Lawan COVID-19 Ditinjau Dari Jenis Kelamin
}

\author{
Aprian Istiono, Mamang Efendy \\ Program Studi Psikologi Profesi (S2) Universitas 17 Agustus 1945 Surabaya \\ Email: aprianistiono.mapro@gmail.com, mamangefendy@untag-sby.ac.id
}

\begin{abstract}
Prosocial behavior and help should be shared by everyone in the face of the COVID-19 pandemic, especially for village volunteers directly involved in providing assistance and assistance in the midst of the COVID-19 pandemic established by the Ministry of Villages PDTT. Prosocial behavior must certainly be owned by village volunteers in carrying out their duties properly. One of the factors that make up prosocial behavior is emotional maturity, emotional maturity plays an important role for volunteers to manage their emotions well in carrying out their duties. The purpose of this study is to find out the relationship between emotional maturity and prosocial behavior as well as differences in emotional maturity and prosocial behavior reviewed from the sexes. The research sample consisted of 72 village volunteers who were randomly selected sampling. Data collection uses emotional maturity scale and self-developed prosocial behavior scale by researchers. Data analysis techniques use simple regression analysis and t-testing. The results showed there was a very significant relationship between emotional maturity and prosocial behavior in village volunteers versus COVID-19. The results also showed no significant differences in prosocial behavior between male volunteers and female volunteers and there was no significant difference in emotional maturity between male volunteers and female volunteers. Which means emotional maturity is an important predictor for prosocial behavior, and prosocial behavior and emotional maturity do not differ between men and women.
\end{abstract}

Keywords: Prosocial Behavior, Emotion Maturity, Village Volunteers Against COVID-19.

\begin{abstract}
Abstrak
Perilaku prososial dan tolong menolong harus dimiliki oleh semua orang dalam menghadapi pandemi COVID19, terutama bagi relawan desa yang terlibat langsung dalam memberikan bantuan dan pertolongan ditengah pandemi COVID-19 yang dibentuk oleh Kementerian Desa PDTT. Perilaku prososial tentunya harus dimiliki oleh relawan desa dalam melaksanakan tugasnya dengan baik. Salah satu faktor yang membentuk perilaku prososial adalah kematangan emosi, kematangan emosi berperan penting bagi relawan untuk mengelola emosinya dengan baik dalam melaksanakan tugasnya. Tujuan penelitian ini untuk mengetahui hubungan antara kematangan emosi dengan perilaku prososial serta perbedaan kematangan emosi dan perilaku prososial ditinjau dari jenis kelamin. Sampel penelitian terdiri dari 72 relawan desa yang dipilih secara random sampling. Pengumpulan data menggunakan skala kematangan emosi dan skala perilaku prososial yang dikembangkan sendiri oleh peneliti. Teknik analisis data menggunakan analisis regresi sederhana dan uji-t. Hasil penelitian menunjukkan ada hubungan sangat signifikan antara kematangan emosi dengan perilaku prososial pada relawan desa lawan COVID-19. Hasil penelitian juga menunjukkan tidak ada perbedaan yang signifikan pada perilaku prososial antara relawan laki-laki dan relawan perempuan serta tidak ada perbedaan yang signifikan pada kematangan emosi antara relawan laki-laki dan relawan perempuan. Yang artinya kematangan emosi menjadi prediktor penting untuk membentuk perilaku prososial, dan perilaku prososial maupun kematangan emosi tidak berbeda antara laki-laki dan perempuan.
\end{abstract}

Kata kunci: Perilaku Prososial, Kematangan Emosi, Relawan Desa Lawan COVID- 19.

\section{Pendahuluan}

Manusia dalam menjalankan kehidupannya selain sebagai makhluk individu, juga menjadi makhluk sosial, yang senantiasa membutuhkan kehadiran dan bantuan dari orang lain dalam kehidupannya. Bahkan setinggi apapun kemandirian seseorang, pada saat-saat tertentu akan membutuhkan orang lain [1]. Kebutuhan berinteraksi dengan orang lain ini juga menjadi salah satu tugas individu dalam melalui tahap perkembangannya [2]. Tugas perkembangan untuk menjalin interaksi sosial tersebut menuntut individu untuk dapat mengembangkan kompetensi sosial, yang salah satunya adalah memberi bantuan tanpa menuntut imbalan. Perilaku memberi bantuan tanpa menuntut imbalan tersebut, bisa jadi justru 
mendatangkan resiko tersendiri bagi individu yang menolong. Perilaku ini dalam psikologi dikenal sebagai prososial [3].

Perilaku prososial tidak hanya dikaitkan dengan kejadian bencana alam atau musibah seperti gunung meletus, gempa bumi, banjir, dan longsor, tetapi juga berkaitan dengan aktivitas lain sehari-hari seperti kerja bakti, menyeberangkan orang lain, mengantarkan tetangga ke rumah sakit untuk berobat, dan lain sebagainya. Perilaku prososial saat ini sangat besar peranannya, terutama setelah pandemi COVID-19 merebak. Di awal tahun 2020 ini, tepatnya sejak tanggal 11 Maret 2020, WHO telah menetapkan virus corona atau COVID-19 sebagai pandemi global. Dunia yang terguncang dengan pandemi COVID-19 ini, harus menghadapi kenyataan bahwa virus ini telah melibatkan kematian di banyak belahan benua dan menuntut tenaga medis bekerja keras menekan penyebarannya dengan melakukan isolasi bagi penderita hingga mensosialisasikan kepada masyarakat tentang perlunya menjaga kebersihan dan jarak antar individu saat berinteraksi (social distancing). Kerja keras tim medis tersebut mendorong berbagai pihak untuk ikut berperan sebagai sukarelawan yang membantu tim medis maupun pemerintah untuk ikut mengurangi resiko penularan di masyarakat secara langsung. Salah satu bentuk prososial yang terwujud adalah dikumpulkannya donasi untuk para tenaga medis, bantuan untuk keluarga atau masyarakat ekonomi bawah yang terdampak, apresiasi untuk tukang ojek dan mereka yang terkena PHK (putus hubungan kerja), bantuan untuk usaha-usaha kecil, dan masih banyak lagi [4].

Menumbuhkan sikap prososial dan rasa saling tolong menolong dalam menghadapi pandemi COVID19 menjadi hal yang sangat penting. Pasalnya kebijakan pembatasan aktivitas berakibat sebagian masyarakat mengalami kesulitan dalam memenuhi kebutuhan hidup sehari-hari. Contoh bentuk kegiatan prososial adalah kegiatan yang tengah viral dilakukan oleh para pedagang sayur yang sedang membagi-bagikan sayuran kepada pengendara motor yang melintas di Dusun Kedungboto, Desa Kedungrejo, Kecamatan Pakis, Kabupaten Malang. Camat Pakis Agus Harianto membenarkan jika yang ada di video itu terjadi di daerahnya, yaitu pada 11 Mei 2020. Karena adanya pandemi corona, sayur-sayuran mereka banyak yang tidak laku. Sehingga para pedagang memilih membagikan dagangan mereka kepada pengendara sepeda motor yang melintas di jalan sekitar pasar, menjelang pasar tutup. Sayur-sayuran yang dibagikan adalah yang masih layak konsumsi [5].

Di sisi lain juga ditemukan potret fenomena berupa tindakan penolakan terhadap pemakaman jenazah pasien positif COVID-19 di sejumlah daerah di Indonesia. Jenazah seorang perawat RSUP dr. Kariadi Semarang yang meninggal dunia karena terinfeksi virus corona ditolak oleh warga untuk dimakamkan di area mereka. Alasannya, khawatir menjadi sumber penyebaran virus corona [6]. Selain itu terjadi juga pengusiran terhadap tenaga medis yang tengah berjuang merawat pasien COVID-19. Tidak mainmain, pengusiran itu dilakukan oleh warga beserta ketua RT setempat. Mereka mengusir 6 tenaga medis Rumah Sakit Siloam Palembang, Sumatera Selatan, yang indekos di satu tempat yang sama. Peristiwa ini terjadi hari Sabtu 18 April di indekos Kelurahan Sungai Pangeran, Kecamatan Ilir Timur I, Palembang. Mereka kini sementara mengungsi ke mes RS Siloam Palembang [7]. Hal yang sama juga terjadi pada pasangan suami istri yang ditolak warga saat pulang ke daerah asalnya di Magetan. Kepala Dinas Kesehatan Kabupaten Magetan Saif Muchlisun menerangkan bahwa pasangan tersebut bekerja sebagai karyawan di pabrik rokok Sampoerna di Surabaya. Diketahui pabrik rokok tersebut menjadi salah satu klaster penularan baru setelah sejumlah karyawannya diketahui positif terkena virus corona [8]. Beberapa gambaran fenomena yang terjadi umumnya dipicu oleh stigma terhadap penderita COVID-19 dan mereka yang berada di garis depan dalam menangani pasien virus corona, serta ketidaktahuan dan kekhawatiran tentang penyebaran virus corona dimasyarakat, selain itu juga akibat rendahnya perilaku prososial di masyarakat dalam bekerjasama dan bersama-sama menghadapi COVID-19.

Pemerintah Indonesia membentuk gugus tugas penanganan COVID-19 pada tanggal 13 Maret 2020. Pembentukan gugus tugas penanganan COVID-19 oleh pemerintah pusat ini kemudian diikuti Kementerian Desa, Pembangunan Daerah Tertinggal Dan Transmigrasi Republik Indonesia yang juga membentuk relawan desa lawan COVID-19. Tujuan dibentuknya relawan desa lawan COVID-19 ini adalah sebagai langkah-langkah pencegahan dan penanganan COVID-19 di desa-desa supaya dapat berjalan secara efektif. Prinsip kerja yang dibuat para relawan desa lawan COVID-19 adalah melaksanakan kegiatan dan aktivitasnya dengan prinsip gotong royong melibatkan dukungan warga masyarakat desa. Anggota relawan desa lawan COVID-19 meliputi Kepala Desa beserta seluruh perangkat desa, seluruh anggota Badan Permusyawaratan Desa, seluruh anggota Lembaga 
Pemberdayaan Masyarakat Desa, seluruh Ketua RW, seluruh Ketua RT, seluruh anggota Karang Taruna Desa, Seluruh Kader PKK dan Posyandu, Bidan Desa, Perawat Pondok Kesehatan Desa, Seluruh anggota Satuan Linmas Desa, Babinsa dari Komando Rayon Militer Kecamatan, Babin Kamtibmas dari Polisi Sektor Kecamatan, dan tokoh masyarakat yang ada di Desa [9].

Bagi seorang relawan, tindakan-tindakan prososial sangat diperlukan, mengingat fungsi relawan adalah seorang yang bersedia dan rela membantu orang lain, ditengah risiko yang harus mereka hadapi. Relawan desa lawan COVID-19 perlu memberikan perhatian penuh secara fisik dan mental untuk mencegah penyebaran COVID-19 semakin meluas meskipun mereka beresiko terpapar.

Menurut [3] faktor-faktor yang mempengaruhi perilaku prososial diantaranya faktor situasional, moral, perbedaan individu dan keadaan emosional. Faktor-faktor tersebut tentu mempengaruhi perilaku prososial pada relawan COVID-19. Misalnya, faktor moral yang menyangkut tanggung jawab korban (tindakan untuk menolong atau tidak menolong bergantung pada pemikiran terhadap orang yang akan ditolong). Termasuk tindakan menolong terhadap orang yang disukai (kesamaan antara penolong dengan orang yang ditolong). Selain itu yang sangat penting dari beberapa faktor yang mempengaruhi perilaku prososial adalah keadaan emosional. Menurut [10] emosi itu sendiri merujuk pada suatu perasaan dan pikiran yang khas, suatu keadaan biologis dan psikologis serta serangkaian kecenderungan untuk bertindak. [11] juga menjelaskan bahwa emosi pada dasarnya mempengaruhi dan memberikan dorongan manusia dalam melakukan tindakan atau mengambil keputusan, mendorong individu memberikan respon atau bertingkah laku terhadap stimulus yang ada, sehingga hal ini menjadi landasan bahwa emosi menjadi sangat penting dalam kaitannya dengan dorongan melakukan tindakan dalam hal ini perilaku prososial. Namun hal yang perlu diperhatikan sebelum individu bereaksi secara emosional adalah kematangan emosi, kematangan emosi pada seseorang membuat dirinya mampu menilai secara kritis tanpa tergesa-gesa dan tidak mengedepankan emosinya terlebih dahulu, mampu mengontrol emosinya di hadapan orang lain dan mampu melihat waktu yang lebih tepat untuk mengungkapkan emosinya dengan cara-cara yang lebih dapat ditentukan [12].

[13] mengatakan bahwa kematangan emosi adalah suatu keadaan atau kondisi mencapai tingkat kedewasaan dari perkembangan emosional dan oleh karena itu pribadi yang bersangkutan tidak lagi menampilkan pola emosional yang pantas bagi anak-anak. Istilah kematangan atau kedewasaan seringkali membawa implikasi adanya kontrol emosi. [14] menyebutkan bahwa gejala-gejala rendahnya kematangan emosi dapat dilihat dari ketidakmampuan merespon stimulus dengan tepat sebagai bentuk dari pengungkapan diri yang tidak baik. Dijelaskan oleh [14] bentuk rendahnya kematangan emosi bisa berupa ketidakmandirian, tidak memiliki kemampuan menerima kenyataan, tidak mampu beradaptasi, tidak mampu merespon dengan tepat stimulus yang ada, tidak mampu berempati, dan tidak mampu menguasai amarah. Kematangan emosi pada relawan COVID-19 dalam melaksanakan tugasnya selain menjadi faktor yang mempengaruhi perilaku prososialnya juga menjadikan relawan COVID-19 akan mampu mengelola emosinya dengan baik, yang kemudian akan membuatnya tidak mudah terbawa emosi dan tetap tenang ketika menghadapi konfrontasi dari orang lain.

Beberapa hasil penelitian menemukan bahwa terdapat hubungan yang positif dan signifikan antara kematangan emosi dengan perilaku prososial [15];[16], selain itu studi lain juga menemukan bahwa kematangan emosi mempengaruhi perilaku prososial [17]. Berdasarkan hasil wawancara terhadap beberapa relawan COVID-19 nampaknya mereka masih merasa kesulitan untuk beradaptasi dengan tuntutan tugas dan tanggung jawab sebagai relawan, karena memiliki pekerjaan utama dalam keseharian selain bertugas menjadi relawan. Bahkan ada juga relawan yang mengeluhkan tidak mampu mengontrol empati sehingga terlalu melonggarkan aturan yang telah dibuat. Misalnya tidak mampu untuk melakukan edukasi ketika ada warga dari luar daerah yang masuk ke dalam desa, karena merasa tidak enak atau sungkan dan takut menyinggung perasaan keluarga yang dikunjungi. Berdasarkan gambaran hasil wawancara tersebut menunjukkan bahwa kematangan emosi pada relawan COVID-19 ini tergolong masih rendah.

Hasil penelitian yang dilakukan oleh [18] menemukan bahwa terjadi perbedaan perilaku prososial antara laki-laki dan perempuan, relawan sosial perempuan mempunyai perilaku prososial lebih tinggi dibandingkan relawan sosial laki-laki. Relawan sosial perempuan lebih menunjukkan perilaku prososial pada aspek persahabatan, bertindak jujur dan berderma, sedangkan relawan sosial laki-laki menunjukkan pada aspek kerja sama dan menolong. Berdasarkan hasil penelitian ini dapat disimpulkan bahwa perempuan bertindak berdasarkan psikis dan laki-laki bertindak berdasarkan pada 
fisik. Berlainan dengan hasil penelitian yang telah dijelaskan sebelumnya, [19] dalam penelitiannya menyebutkan bahwa terdapat perbedaan perilaku prososial remaja laki-laki dan perempuan. Remaja laki- laki memiliki perilaku prososial lebih tinggi dibandingkan dengan perempuan. Hal ini dikarenakan remaja laki-laki di Kelurahan Tanjung Rejo Medan Sunggal dalam berperilaku prososial mereka lebih cepat dalam mengambil keputusan serta mampu menghadapi situasi yang menantang dan beresiko. Sedangkan remaja perempuan tampak masih ragu-ragu dan merasa takut akan resiko yang ditimbulkan dari berperilaku prososial.

\section{Metode Penelitian}

\section{Subjek}

Populasi pada penelitian ini adalah seluruh anggota Relawan Desa Lawan COVID-19 yang ada di Desa Wilayut Kecamatan Sukodono Kabupaten Sidoarjo sejumlah 85 orang. Anggota relawan desa lawan COVID-19 meliputi Kepala Desa beserta seluruh Perangkat Desa, seluruh anggota Badan Permusyawaratan Desa, seluruh anggota Lembaga Pemberdayaan Masyarakat Desa, seluruh Ketua RW Desa, seluruh Ketua RT Desa, seluruh anggota Karang Taruna Desa, Seluruh Kader PKK dan Posyandu Desa, Bidan Desa, Perawat Pondok Kesehatan Desa, Seluruh anggota Satuan Linmas Desa, Babinsa dari Komando Rayon Militer Kecamatan Sukodono, Babin Kamtibmas dari Polisi Sektor Kecamatan Sukodono, dan tokoh masyarakat yang ada di Desa Wilayut. Adapun sampel dalam penelitian ini sebanyak 72 orang yang diambil secara random sampling.

Instrumen Pengumpulan Data

Pengumpulan data dalam penelitian ini menggunakan skala perilaku prososial dan skala kematangan emosi yang disusun sendiri oleh peneliti, melalui serangkaian prosedur pengembangan alat ukur, uji validitas dan reliabilitas.

\section{Analisis Data}

Analisis data dalam penelitian ini menggunakan analisis regresi sederhana untuk mengetahui hubungan kematangan emosi dan perilaku prososial dan uji t untuk mengetahui perbedaan perilaku sosial antara relawan laki-laki dan perempuan.

\section{Hasil dan Pembahasan}

Hasil perhitungan analisis regresi sederhana untuk mengetahui hubungan kematangan emosi dan perilaku prososial, ditunjukkan dengan tabel berikut:

\begin{tabular}{|c|c|c|}
\hline Model & $\mathbf{F}$ & p \\
\hline Regression & 182,270 & 0,000 \\
\hline
\end{tabular}

Berdasarkan tabel diatas hasil analisis regresi sederhana diperoleh nilai $\mathrm{F}=182,270$ dengan signifikansi $0,000(\mathrm{p}<0,01)$ berarti menunjukan ada hubungan yang sangat signifikan antara kematangan emosi dengan prososial. Dari hasil tersebut maka hipotesis pertama yang berbunyi ada hubungan yang positif antara kematangan emosi dengan perilaku prososial pada relawan desa lawan COVID-19 diterima.

\begin{tabular}{cccc} 
& Tabel 2. Analisis Uji t Perilaku Prososial & t & p (2- tailed) \\
\hline Variabel & Jenis Kelamin & 0,591 & 0,556 \\
\hline Perilaku prososial & Laki-laki & 0,591 & \\
\hline & Perempuan &
\end{tabular}

Berdasarkan tabel diatas didapatkan nilai t perilaku prososial relawan laki-laki sebesar 0,591 dan nilai t perilaku prososial relawan perempuan sebesar 0,591. Hal ini menunjukkan secara deskriptif statistik tidak terdapat perbedaan nilai t perilaku prososial antara relawan laki-laki dan relawan perempuan. Hasil independent sample t-test dengan signifikansi (2-tailed) sebesar 0,556 ( $\mathrm{p}>0,05)$, maka dapat diartikan tidak ada perbedaan yang signifikan (nyata) antara perilaku prososial pada relawan laki-laki dengan relawan perempuan. Dari hasil tersebut maka hipotesis kedua yang berbunyi ada perbedaan perilaku prososial pada relawan laki-laki dengan relawan perempuan tidak diterima/ditolak.

\begin{tabular}{cccc} 
& Tabel 3. Analisis Uji t Kematangan Emosi & t & p (2- tailed) \\
\hline Variabel & Jenis Kelamin & 0,173 & 0,863 \\
\hline Lematangan Emosi & Laki-laki & 0,173 & \\
\hline Perempuan & Sumber: Output Statistics Program SPSS Seri 20 IBM for Windows
\end{tabular}


Berdasarkan tabel diatas didapatkan nilai t kematangan emosi relawan laki- laki sebesar 0,173 dan nilai t kematangan emosi relawan perempuan 0,173 . Hal ini menunjukkan secara deskriptif statistik tidak terdapat perbedaan nilai t kematangan emosi antara relawan laki-laki dan relawan perempuan. Hasil independent sample t- test dengan signifikansi (2-tailed) sebesar 0,863 ( $p>0,05$ ), maka dapat diartikan tidak ada perbedaan yang signifikan (nyata) antara kematangan emosi pada relawan laki-laki dengan relawan perempuan. Dari hasil tersebut maka hipotesis ketiga yang berbunyi ada perbedaan kematangan emosi pada relawan laki-laki dengan relawan perempuan tidak diterima/ditolak.

Diterimanya hipotesis pertama dalam penelitian ini yang berbunyi ada hubungan yang positif antara kematangan emosi dengan perilaku prososial pada relawan desa lawan COVID-19, menunjukkan bahwa ada hubungan yang sangat signifikan antara kematangan emosi dengan perilaku prososial pada relawan desa lawan COVID-19. Artinya kematangan emosi dapat memprediksi perilaku prososial pada relawan desa lawan COVID-19. Konteks dalam penelitian adalah para relawan desa lawan COVID-19 di Desa Wilayut Kecamatan Sukodono Kabupaten Sidoarjo, dimana para relawan ini dituntut untuk berperilaku prososial, mengingat fungsi relawan sendiri sebagai seorang yang bersedia atau rela membantu orang lain, meskipun relawan memiliki risiko sangat besar terkena dampak psikologis dan psikososial dari tugas kemanusiaan yang diemban. Bagi seorang relawan menjadi penting memiliki kematangan emosi, karena relawan yang memiliki kematangan emosi sikap dan perilakunya akan mampu menerima kenyataan yang ada, mampu mengontrol emosi, mampu berempati dan mampu mengontrol diri sendiri, karena memiliki sikap dan perilaku seperti itu, maka dampak terhadap sikap dan perilakunya secara prososial akan juga menjadi baik, yang ditandai dengan kesediaan berbagi, kesediaan bekerjasama, kesediaan menolong, kesediaan untuk selalu jujur, dan kesediaan untuk menyumbang secara sukarela tanpa mengharapkan imbalan dari orang yang ditolong.

Hasil penelitian menemukan bahwa relawan yang memiliki kematangan emosi maka sikap dan perilakunya akan dapat menerima kenyataan yang ada dilingkunganya, artinya relawan akan dapat menerima baik keadaan dirinya maupun orang lain seperti apa adanya secara realistis dan objektif, akan menjadikan relawan bersedia melaksanakan sesuatu seperti yang di amanahkan, tidak berbuat curang atau jujur dan tulus mengakui perasaan, sehingga dampak pada perilaku prososialnya akan menjadi baik. Contohnya ketika relawan desa lawan COVID-19 mampu menerima kenyataan adalah ketika dirinya tidak termasuk dalam daftar penerima bantuan sosial selama masa pandemi COVID-19, relawan tersebut secara bersamaan mampu menerima kenyataan kalau ada orang lain yang lebih berhak dan sesuai dengan aturan pemerintah terkait penerima bantuan sosial, yang selanjutnya akan membuat relawan tersebut akan mampu menjelaskan kepada masyarakat terkait peraturan penerima bantuan sosial yang dibuat oleh pemerintah supaya tidak terjadi kecemburuan sosial di masyarakat.

Relawan yang memiliki kematangan emosi juga ditandai dengan beberapa ciri-ciri yang lain, seperti dapat mengontrol emosi secara baik, walaupun relawan tersebut dalam keadaan marah tetapi marahnya itu tidak ditampakkan keluar, karena relawan tersebut dapat mengatur kapan kemarahan itu perlu dimanifestasikan, sehingga dalam melakukan kegiatan bersama dengan orang lain termasuk diskusi dan melaksanakan suatu tindakan akan dapat terlaksana dengan baik guna tercapainya suatu tujuan bersama, yang bisa diartikan dampak perilaku prososialnya akan menjadi lebih baik. Contoh ketika relawan desa lawan COVID-19 mampu mengontrol emosi adalah mampu berkoordinasi dengan relawan yang lain ketika akan melakukan tindakan di lapangan supaya tidak salah langkah, seperti akan mengkoordinasikan dengan pihak terkait supaya lingkungan tidak mengucilkan orang yang dinyatakan terpapar COVID-19.

Ciri relawan yang sudah matang emosinya selanjutnya ditandai dengan kemampuan berempati dalam arti memiliki sifat sabar, pengertian, dan umumnya cukup mempunyai toleransi yang baik dalam memahami apa yang orang lain pikirkan atau rasakan, yang kemudian akan menjadikan relawan bersedia untuk membantu meringankan beban orang lain yang sedang berada dalam kesulitan dengan melakukan kegiatan fisik ataupun menyumbang materi secara sukarela tanpa mengharapkan balasan dari orang yang ditolong. Dampak dimilikinya kemampuan berempati tersebut akan membuat perilaku prososial relawan desa lawan COVID-19 menjadi lebih baik. Contoh relawan desa lawan COVID-19 yang memiliki kemampuan berempati adalah mampu memahami pikiran dan perasaan orang lain yang terpapar COVID-19 hingga mereka harus mengisolasi diri secara mandiri, sehingga relawan tersebut akan bersedia menolong untuk membelikan kebutuhan sehari-hari orang lain yang dalam masa isolasi mandiri. 
Ciri terakhir dari relawan yang memiliki kematangan emosi adalah ditandai dengan kemampuan mengontrol diri sendiri dalam arti mempunyai tanggung jawab yang baik, dapat berdiri sendiri dan tidak mudah mengalami frustasi akan membuat relawan menghadapi masalah dengan penuh pertimbangan, sehingga ketika relawan telah mampu mengontrol diri sendiri, relawan tersebut akan memiliki kesediaan untuk membagi perasaan dengan orang lain dalam suasana suka dan duka dengan memberi kesempatan serta perhatian kepada orang lain untuk mencurahkan isi hatinya, yang berdampak pada perilaku prososialnya akan menjadi baik. Contoh relawan desa lawan COVID-19 yang mampu mengontrol diri sendiri adalah mampu mencari cara dengan sesama anggota relawan supaya tidak spaneng dan jenuh ketika bertugas.

Istilah kematangan atau kedewasaan seringkali membawa implikasi adanya kontrol emosi. Hal tersebut sesuai dengan hasil wawancara peneliti dengan beberapa anggota relawan desa lawan COVID-19 yang menjelaskan pentingnya kontrol emosi dalam menjalankan tugas sebagai relawan. Mayoritas relawan yang merupakan stakeholder di Desa Wilayut, menjelaskan kalau mereka sangat sering ditanya dan dimintai penjelasan oleh warganya terkait bantuan sosial ataupun kebijakankebijakan pemerintah terkait penanganan COVID-19 yang ada di Desa Wilayut Kecamatan Sukodono Kabupaten Sidoarjo.

Beberapa contohnya kejadian yang dialami oleh relawan desa lawan COVID- 19 adalah tentang bantuan sosial. Mereka menjelaskan semenjak adanya wabah virus corona banyak sekali kegelisahan di warganya yang terjadi. Contohnya adalah warga yang menjadi sensitif apabila ada tetangga mereka yang memperoleh bantuan sosial baik tunai ataupun non-tunai, sedangkan ada sebagian dari mereka yang tidak memperoleh bantuan sosial tersebut. Menurut penjelasan anggota relawan desa lawan COVID-19 kejadian tersebut dikarenakan warga yang bersangkutan tidak lagi memiliki penghasilan untuk mencukupi kebutuhan keluarganya karena terkena PHK (putus hubungan kerja). Sehingga ketika melihat ada tetangga yang memperoleh bantuan sosial tetapi diri mereka tidak mendapatkan, hal terebut memicu emosi warga tersebut.

Relawan desa lawan COVID-19 dalam menghadapi situasi seperti diatas dituntut untuk mampu mengontrol emosi diri sendiri supaya tidak ikut terbawa emosi dan selanjutnya menjelaskan kepada warganya tersebut dengan tenang dan semampunya. Namun apabila warga tersebut masih belum puas dengan penjelasan yang telah diberikan, relawan desa lawan COVID-19 dapat mengarahkan warga tersebut untuk menemui Kepala Desa selaku pimpinan relawan desa lawan COVID- 19 yang ada di Desa, dengan tujuan supaya mendapatkan penjelasan yang lebih jelas.

Beberapa kejadian yang teramati oleh peneliti tersebut bisa menjadi gambaran bahwa keadaan emosional relawan dikatakan matang apabila telah dapat mengendalikan emosinya, maka relawan akan dapat berpikir secara matang dan baik, serta objektif. Maka kebalikan dari relawan yang memiliki kematangan emosi, adalah apabila relawan yang keadaan emosinya belum matang, bisa diamati dari gejala-gejalanya berupa ketidakmampuan merespons stimulus dengan tepat sebagai bentuk dari pengungkapan diri yang tidak baik. Bentuk emosi yang belum matang juga bisa berupa ketidakmandirian, tidak memiliki kemampuan menerima kenyataan, tidak mampu beradaptasi, tidak mampu merespons dengan tepat stimulus yang ada, tidak mampu berempati, dan tidak mampu menguasai amarah.

Hasil uji data penelitian menggunakan analisis regresi linier sederhana menunjukkan ada pengaruh kematangan emosi terhadap perilaku prososial, dilihat dari koefisien determinasi variabel kematangan emosi dengan perilaku prososial sebesar $72,3 \%$, yang bisa diartikan $27,7 \%$ perilaku prososial dibentuk oleh faktor lain yang tidak diikutkan dalam penelitian ini diantaranya adalah faktor situasional, moral, dan perbedaan individu. Kontribusi yang cukup besar yaitu 72,3\% menunjukkan bahwa variabel kematangan emosi cukup penting dalam memberikan pengaruh terhadap perilaku prososial khususnya pada relawan desa lawan COVID- 19 yang menjadi subjek penelitian. Bisa diartikan dalam usaha berperilaku prososial selama bertugas sebagai relawan, para anggota relawan desa lawan COVID-19 perlu memiliki kematangan emosi yang baik.

Ada beberapa faktor yang mempengaruhi para relawan COVID-19 tersebut tetap melakukan prososial dengan baik, salah satunya adalah keadaan emosional. Keadaan emosional individu dikatakan matang apabila telah dapat mengendalikan emosinya, maka individu akan dapat berpikir secara matang, berpikir secara baik dan objektif, oleh karena itu pribadi yang bersangkutan tidak lagi menampilkan pola emosional yang pantas bagi anak-anak. Sesuai dengan hasil penelitian yang dilakukan oleh [20] 
yang menjelaskan bahwa terdapat hubungan positif yang sangat signifikan antara kematangan emosi dengan perilaku prososial pada relawan LSM HIV/AIDS di kota Medan.

Hasil penelitian ini sejalan dengan penelitian yang dilakukan secara terpisah oleh [20]; [21];[16] tentang hubungan kematangan emosi, empati, religiositas dan perilaku prososial. Hasil dari penelitianpenelitian tersebut menjelaskan bahwa ada hubungan positif dan signifikan antara kematangan emosi mempengaruhi perilaku prososial.

Ditolaknya hipotesis kedua dalam penelitian ini yang berbunyi ada perbedaan perilaku prososial pada relawan laki-laki dengan relawan perempuan, menunjukkan bahwa tidak ada perbedaan yang signifikan antara perilaku prososial pada relawan laki-laki dengan relawan perempuan. Begitu juga ditolaknya hipotesis ketiga dalam penelitian ini yang berbunyi ada perbedaan kematangan emosi pada relawan laki- laki dengan relawan perempuan, menunjukkan bahwa tidak ada perbedaan yang signifikan antara kematangan emosi pada relawan laki-laki dengan relawan perempuan. Ditolaknya hipotesis kedua dan ketiga tersebut menunjukkan bahwa hasil penelitian ini tidak mendukung penelitian sebelumnya yang dilakukan oleh [18] yang dalam penelitiannya mendapatkan hasil bahwa relawan sosial perempuan mempunyai perilaku prososial lebih tinggi dibandingkan relawan sosial laki-laki. Berlainan dengan hasil dari olah data dalam penelitian ini yang menunjukkan tidak ada perbedaan yang signifikan (nyata) antara kematangan emosi dan perilaku prososial pada relawan lakilaki dengan relawan perempuan. Sehingga baik pada relawan laki-laki maupun relawan perempuan sama-sama saling memiliki kematangan emosi dan perilaku prososial.

Perbedaan hasil penelitian wajar terjadi karena mengingat beberapa perbedaan kajian yang dilakukan. Apabila dalam penelitian terdahulu yang dilakukan oleh [18] kajian penelitian yang dilakukan hanya difokuskan pada perilaku prososial yang dimiliki relawan sosial laki-laki dan perempuan, sedangkan variabel kematangan emosi tidak dijadikan variabel yang dikaji. Selain itu pada penelitian terdahulu subjek penelitian bukan relawan yang dikhususkan untuk menangani pandemi COVID-19, namun relawan sosial yang bekerja sebelum adanya pandemi COVID-19. Penelitian terdahulu tidak dijelaskan wilayah tempat tinggal relawan sosial yang dijadikan subjek, sedangkan pada penelitian ini relawan yang dijadikan subjek adalah relawan desa lawan COVID-19 di Desa Wilayut Kecamatan Sukodono Kabupaten Sidoarjo.

Melihat ditolaknya hipotesis kedua dan ketiga penelitian, peneliti menemukan penelitian sejenis yang hasilnya sama. Penelitian tersebut dilakukan oleh [21] yang meneliti perilaku prososial ditinjau dari empati dan kematangan emosi. Hasil penelitian tersebut menunjukkan bahwa tidak terdapat perbedaan skor prososial antara laki-laki dan perempuan, sehingga dapat disimpulkan bahwa perbedaan stereotype tidak menyebabkan perbedaan dalam perilaku prososial. Kesamaan dalam penelitian terdahulu dan penelitian yang dilakukan oleh peneliti ini adalah rentang usia dari subjek penelitian yang sama-sama telah berada di usia dewasa awal hingga dewasa madya. Melihat usia subjek yang dalam masa dewasa secara perkembangan mental telah berada di awal masa kematangan emosi. Sehingga ketika diukur variabel kematangan emosi dan perilaku sosial yang dimiliki bisa mendapatkan hasil yang maksimal. Maka usia subjek perlu menjadi fokus perhatian ketika akan mengukur kematangan emosi dan perilaku prososial seseorang.

\section{Kesimpulan}

Menumbuhkan sikap prososial dan rasa saling tolong menolong dalam menghadapi pandemi COVID19 menjadi hal yang paling diperlukan. Salah satu upaya menumbuhkan sikap prososial adalah dengan dibentuknya relawan desa lawan COVID-19 oleh Kementerian Desa PDTT. Bagi seorang relawan, tindakan- tindakan prososial memang sangat dituntut, mengingat fungsi relawan sendiri sebagai seorang yang bersedia atau rela membantu orang lain, meskipun relawan memiliki risiko sangat besar terkena dampak psikologis dan psikososial dari tugas kemanusiaan yang diemban. Ada beberapa faktor yang mempengaruhi para relawan COVID-19 tersebut tetap melakukan prososial dengan baik, salah satunya adalah kematangan emosi. Bagi seorang relawan menjadi penting memiliki kematangan emosi karena dengan dimilikinya kematangan emosi dalam melaksanakan tugasnya relawan akan mampu mengelola emosinya, yang kemudian akan membuatnya berperilaku prososial dengan baik.

Tujuan dari penelitian ini adalah untuk mencari hubungan antara variabel kematangan emosi dengan perilaku prososial. Subjek dalam penelitian ini adalah relawan desa lawan COVID-19 di Desa Wilayut Kecamatan Sukodono Kabupaten Sidoarjo. Teknik analisis data menggunakan analisis regresi sederhana untuk mengukur pengaruh variabel bebas terhadap variabel tergantung dan uji-t 
(independent sample t-test) untuk melihat ada atau tidaknya perbedaan antar kelompok (relawan lakilaki dan relawan perempuan) dengan bantuan program IBM SPSS Statistics 20.

Hasil penelitian yang pertama menyatakan bahwa terdapat hubungan yang sangat signifikan antara kematangan emosi dengan prososial pada relawan desa lawan COVID-19, sehingga variabel kematangan emosi dapat memprediksi perilaku prososial. Hasil penelitian yang kedua menyatakan tidak ada perbedaan yang signifikan antara perilaku prososial pada relawan laki-laki dengan relawan perempuan. Sehingga baik pada relawan laki-laki maupun relawan perempuan sama- sama saling memiliki perilaku prososial. Hasil penelitian yang ketiga menyatakan tidak ada perbedaan yang signifikan antara kematangan emosi pada relawan laki-laki dengan relawan perempuan. Sehingga baik pada relawan laki-laki maupun relawan perempuan sama-sama saling memiliki kematangan emosi.

\section{Daftar Rujukan}

[1] Faturochman, Pengantar psikologi sosial. Yogyakarta: Pustaka Book Publishing., 2016.

[2] E. B. Hurlock, "Psikologi Perkembangan: Suatu Pendekatan Sepanjang Rentang Kehidupan, Edisi 5, Cetakan Keempat.” Jakarta: Percetakan PT. Gelora Aksara Pratama. Penerbit Erlangga (anggota IKAPI), 1991.

[3] R. A. Baron and D. Byrne, "Psikologi sosial (edisi 10)," Jakarta: Erlangga, 2005.

[4] Rachmatunnisa, "Kisah-kisah mengharukan saling tolong di tengah pandemi COVID-19." Detiknews.com, 2020.

[5] F. Shalihah, N, "Viral video pedagang membagikan sayuran gratis di jalan, ini faktanya." 2020.

[6] L. . Azanella, "Penolakan jenazah pasien COVID-19, mengapa bisa terjadi?" Kompas, 2020.

[7] R. Gunadha, "perawat RS Siloam diusir Pak RT dan warga dari kos, takut virus corona.” 2020.

[8] N. Primaresti, "imbas pasutri karyawan Sampoerna ditolak warga karena corona, anaknya usia SD dikarantina terpisah.” Tribunnews.com, 2020.

[9] Rusli, "KEMENDES PDTT bentuk relawan desa tanggap COVID-19." https://www.kemendesa.go.id/berita/view/detil/3210/kemendes- pdtt-bentuk-relawan-desa-tanggapcovid-19., 2020.

[10] D. Goleman, Working with emotional intelligence. Kecerdasan emosi untuk mencapai puncak prestasi. Jakarta: PT. Gramedia Pustaka Utama., 2002.

[11] Goleman, Emotional Intelligence. Jakarta: PT. Gramedia, 2008.

[12] W. Bimo, Bimbingan dan Konseling Studi Karir. Yogyakarta: Andi, 2010.

[13] J. P. Chaplin, "Kamus Lengkap Psikologi. Jakarta: PT Raja Grafindo." 2006.

[14] W. Katkovsky and L. Gorlow, The psychology of adjustment: current concepts and applications. McGraw-Hill Companies, 1976.

[15] Q. A'yun, "Hubungan kematangan emosi dengan perilaku prososial pada siswi smp babussalam pekanbaru," Universitas Islam Negeri Sultan Syarif Kasim Riau, 2015.

[16] T. D. Haryati, "Kematangan emosi, religiusitas dan perilaku prososial perawat di rumah sakit," Pers. J. Psikol. Indones., vol. 2, no. 2, 2013.

[17] R. Trifiana, "Pengaruh Kematangan Emosi Terhadap Perilaku Prososial Remaja Pengguna Gadget di SMP N 2 Yogyakarta," J. Ris. Mhs. Bimbing. Dan Konseling, 2015.

[18] R. Fitroh, W. K. Oktavia, and H. Hanifah, "Perbedaan perilaku prososial ditinjau dari jenis kelamin pada relawan sosial," J. Psikol. Terap. dan Pendidik., vol. 1, no. 1, pp. 9-15, 2019.

[19] I. Istiana, "PERBEDAAN PERILAKU PROSOSIAL REMAJA DITINJAU DARI JENIS KELAMIN DI KELURAHAN TANJUNG REJO MEDAN SUNGGAL,” J. Divers., vol. 4, no. 1, pp. 58-67, 2018.

[20] S. Novira, "Hubungan antara kematangan emosi dengan perilaku prososial pada relawan LSM HIV / AIDS di Kota Medan," Universitas Medan Area, 2009.

[21] G. Y. Asih and M. M. S. Pratiwi, "Perilaku prososial ditinjau dari empati dan kematangan emosi," $J$. Psikol. umk pitutur, vol. 1, no. 1, pp. 33-42, 2010. 